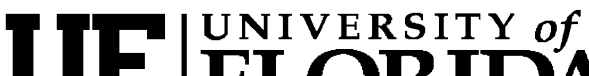 FLORIDA \\ IFAS Extension
}

FCS3305

\section{Reverse Mortgages: Understanding the Basics ${ }^{1}$}

\author{
Michael S. Gutter, Selena Garrison, Brent Litchfield, and Lisa Leslie ${ }^{2}$
}

\section{Introduction}

For most people, their largest single investment is usually the home in which they reside. One thing that most families don't realize is how to utilize this investment of equity in their house to help fund their retirement. You could sell your house and use those funds for retirement, but an obvious problem you would run into is that you still need a place to live during your retirement. This would also mean that a family home would no longer be in the family and would not be in the estate. Most of the money earned from selling your house would then have to be turned around and used to either buy or rent a new house. Another option is to take out a loan against your house, such as home equity loan or a home equity line of credit. Unfortunately with this option, you would be required to make monthly loan repayments and pay interest on your loan. One last option that you have is to use a reverse mortgage.

\section{Is a reverse mortgage a loan?}

Yes. A reverse mortgage is a loan that allows a homeowner to receive cash on some of the equity in their home in the form of tax-free cash flows. It is different from a home equity loan because reverse mortgages do not require payment while the borrower lives in the home and maintains it as the borrower's primary residence. While this option may be very good for some people, reverse mortgages are not right for everyone. As with every decision we make, it is important to weigh the pros and cons.

There is no income requirement for applying for a reverse mortgage. Instead of making monthly payments, you receive them. However, the amount that you owe continually grows larger with each payment received. The interest charged is added to the outstanding loan balance each month. Because of this, reverse mortgages reduce home equity, leaving fewer assets for heirs. Some people may use life insurance to offset this loan. One concern is that someone may end up owing more than the house is worth because of decline in its value. Borrowers and their estates are protected by the "nonrecourse" clause. This clause, found in most reverse mortgages, prevents the homeowner or the heirs from being responsible for more than the value of the home when the loan is being repaid.

One of the most appealing characteristics of reverse mortgages is the fact that the loan requires no repayment during the lifetime of the borrower.

1. This document is FCS3305, one of a series of the Department of Family, Youth and Community Sciences, Florida Cooperative Extension Service, Institute of Food and Agricultural Sciences, University of Florida. Original publication date October 2009. Visit the EDIS Web site at http://edis.ifas.ufl.edu.

2. Michael S. Gutter, assistant professor and family financial management specialist; Selena Garrison, graduate student; Brent Litchfield, undergraduate student; Lisa Leslie, extension agent for Hillsborough County; Department of Family, Youth and Community Sciences; Institute of Food and Agricultural Sciences; University of Florida; Gainesville 32611.

The Institute of Food and Agricultural Sciences (IFAS) is an Equal Opportunity Institution authorized to provide research, educational information and other services only to individuals and institutions that function with non-discrimination with respect to race, creed, color, religion, age, disability, sex, sexual orientation, marital status, national origin, political opinions or affiliations. U.S. Department of Agriculture, Cooperative Extension Service, University of Florida, IFAS, Florida A. \& M. University Cooperative Extension Program, and Boards of County Commissioners Cooperating. Millie FerrerChancy, Interim Dean 
However, the loan could be required to be repaid in full, including all interest and other charges, when the last living borrower dies, or the borrower rents or sells the home or part of the home, permanently moves away, takes out new debt on the home, adds a new owner to the home's title, or changes the home's zoning. Although you may owe a sizable amount of your equity when you use a reverse mortgage, most lenders won't want your house when the loan is due. They'll just want their money back plus interest. Your heirs could pay back the reverse mortgage using a standard mortgage, or they could sell the house and use the proceeds to pay off the loan.

Another important thing to remember is that you are still the owner of your home when you get a reverse mortgage. This means that you are still responsible for property taxes, insurance, and repairs. This is an important consideration because if you fail to carry out these homeowner responsibilities, your loan could become due and payable in full.

\section{Requirements}

You might be wondering at this point what the requirements are for applying for a reverse mortgage. To qualify for a reverse mortgage, you must:

- Be at least 62 years of age

- Own the property that the reverse mortgage is tied to

- Live in the property as your principal residence

- Have substantial home equity

- Not have another loan or mortgage on your house, or be willing to pay it off either before or immediately after obtaining a reverse mortgage

- Not be delinquent of federal debt such as back taxes

- Meet with an approved counselor to discuss eligibility requirements, financial implications, alternatives, and provisions. It would be wise to research reverse mortgages before the counseling session so you can prepare your list of questions ahead of time.
All owners of the home must apply for the mortgage and sign the loan papers. For example, if you and your spouse both own your home and are both over 62 years of age, both of you have to apply for the mortgage and sign all of the loan papers in order to qualify.

The Property must meet one of the following requirements:

- Single family house

-1-4 unit home with one unit being occupied by the borrower(s)

- HUD-approved condominium

- Manufactured house that meets Federal Housing Administration (FHA) requirements

\section{Who should consider a reverse mortgage?}

- Someone planning to remain in their primary residence during retirement

- Someone who lost more than they could sustain in the market and needs to have additional cash flow production

\section{Who should not consider a reverse mortgage?}

- Someone not comfortable with the risks

- Someone wishing to keep a home in the family

- Someone who thinks they are not likely to remain very long in their home after taking out a reverse mortgage

\section{Cost Considerations of Reverse Mortgages}

As stated previously, reverse mortgages are a way for a homeowners to take equity out of their home, yet remain in the home. However, this type of loan is likely to be more expensive than other types of loans such as home equity loans or lines of credit. The fees and upfront costs associated with a reverse mortgage are likely to be especially expensive for a 
homeowner who stays in the home only a few years. Alternatively, a homeowner who remains in the home for a long time may find they have little home equity left to tap for emergencies, home maintenance, or if a move to assisted living is needed. Due to the high costs and reduced equity, a homeowner should think carefully before using this type of loan to finance non-essentials, and possibly consider consulting a professional financial advisor who can review their unique situation.

\section{Alternatives to Reverse Mortgages}

When considering reverse mortgages, a consumer should also consider alternative options. Would it be more cost-effective to sell the home and downsize to something smaller? If a reverse mortgage is being considered for reasons such as home repairs or delinquent taxes, is there a possibility of assistance from local or state agencies? Would a home equity loan or line of credit be a less expensive option? Is there a good chance that the home's equity will be needed for another purpose? Is there enough information; do you still have questions? Are there things that you don't fully understand when it comes to reverse mortgages? If you answered "yes" to any of the above, a reverse mortgage might not be your best choice. You should continue to research your individual options, and possibly seek professional advice.

\section{Types of Reverse Mortgages}

Reverse mortgages are categorized as either Public Sector Loans or Private Sector Loans.

Public Sector Loans: offered by state and local governments; generally must be used for specific purposes, such as paying for home repairs or property taxes. These loans typically have lower costs and therefore give higher cash benefits. Public sector loans consist of two types, single-purpose loans and HECMs.

- Single-purpose reverse mortgages are offered by some state and local agencies and some non-profit organizations. According to the AARP, single purpose reverse mortgages usually have the lowest cost structure, and are only available to low to moderate income homeowners. This type of loan can only be used for a specified purpose, such as home improvements or property taxes.

- Home Equity Conversion Mortgages (HECMs) are federally insured reverse mortgages that are guaranteed by the U.S. government through HUD (U.S. Department of Housing and Urban Development), which is responsible for developing and enforcing housing policy. HECMs are allowed to be used for any purpose the borrower desires. HECMs are the most popular reverse mortgage, and consist of roughly $90 \%$ of all reverse mortgages. These loans typically allow larger loan advances and are best used with houses that are worth less than $\$ 400,000$.

Private Sector Loans: offered by banks, mortgage companies, and savings associations; can be used for any purpose. Private sector loans come in the form of proprietary loans.

- Proprietary reverse mortgages are private loans backed by the companies that develop them. Proprietary reverse mortgages may offer larger home value limits to borrowers, but tend to be more expensive. If your home is worth more than the $\$ 625,500$ HECM loan limit (as of 2009), this type of loan could give you larger cash advances. Like HECMs, proprietary loans can be used for any purpose.

The differences in available loan amounts can vary greatly between plans, and the amount of cash you can get depends on the specific reverse mortgage plan or program you select.

\section{Reverse Mortgage Fees \& Interest}

It is important to recognize that there are some costs associated with getting a reverse mortgage. Due to the way that reverse mortgages are structured, they are most expensive in the early years of the loan, and then become less costly afterwards. This means that the cost may be very high up front, but lessens the longer you have the loan. 
Total Annual Loan Cost (TALC) disclosure statements are given by lenders to evaluate the average annual costs of a reverse mortgage and can be used to help a buyer compare different mortgages. In general, costs are the highest when a borrower only lives in the home a short time after receiving the loan. It usually benefits the borrower to keep the loan for longer durations, which allows the fees to be depreciated out over the course of the loan. Keep in mind though, that like all loans, the longer a loan is held, the longer the interest compounds. You should figure out if and when a reverse mortgage best suits you before meeting with a lender.

Keep in mind that although the IRS does not generally consider loan advances to be income, the possible tax implications of sales might impact the homeowner's heirs. The loan may also impact Supplemental Security Income. In addition, getting a reverse mortgage might impact Medicaid benefits if the funds come in a lump sum or if you let the funds accumulate in a savings or checking account for a while. You should look into how a reverse mortgage would impact your situation before applying for one.

\section{Fees}

There are quite a few fees associated with reverse mortgages that you should be familiar with. Most fees can be financed as part of the loan. There are two main fees that are unique to reverse mortgages: the origination fee and the mortgage insurance premium.

- Origination Fee: the upfront fee charged by the reverse mortgage lender to initiate the loan. For the HECM, the origination fee is 2 percent of the maximum loan amount up to $\$ 200,000$, and 1 percent on the remainder of the loan amount. However, the origination fee cannot be less than $\$ 2,500$ or more than $\$ 6,000$ no matter the loan amount.

\section{- Mortgage Insurance Premium (MIP):}

protects the borrower. HUD has guidelines that require all HECM reverse mortgage borrowers to receive reverse mortgage insurance, which guarantees two things. First, it guarantees that you will continue to receive benefits no matter what happens to your investor. If your lender suddenly went out of business or leaves for any other reason, the government would step in and pay the loan payments. Second, MIP ensures that you will never owe more than the value of the home, even if the value of your house declines, or you occupy the home longer than expected. The Mortgage Insurance Premium is 2 percent of home's value, with a home value limit of $\$ 625,500$, and an annual premium of 0.5 percent of the loan balance.

In addition to these two fees, there are all the other fees that are normally associated with any mortgage.

- Application Fee: Banks usually charge this fee to determine your ability to take on new credit, check your credit score, and to process your mortgage application.

- Appraisal Fees: paid to have an expert estimate the market value of your home. This fee is usually unavoidable because it is required every time a house is sold.

- Third Party Closing Costs: covers services that are required before the reverse mortgage can be finalized; includes such things as appraisals, title searches, surveys, inspections, mortgage taxes, and credit checks, as well as others.

- Servicing Set Aside Fee: used to cover the future costs of services, such as account statements, paying out loan income, and checking that loan requirements are being kept. Typically these fees are between $\$ 20$ and $\$ 35$, and are capped by the federal government at $\$ 30$ if the interest rate is annually adjusted and at $\$ 35$ if the interest rate is adjusted monthly. The Servicing Set-Aside is not added to the principal of the loan initially, but is applied to the loan balance on a monthly basis throughout the loan.

\section{Interest}

Like all loans, there is interest charged on a reverse mortgage. While you should always try and minimize fees, interest is going to be the largest cost in a reverse mortgage. Luckily, no matter how much interest is accumulated, you will never be required to 
pay back more than the value of the property.

Borrowers should become familiar with the following terms.

- Index Base Rate: The index base rate is the benchmark index on which the mortgage rate is based. The benchmark would be one of several published financial indices. This rate differs and changes over time. HECMs are usually based off of the 1-year Treasury bill rate.

- Margin: The profit margin is the difference between the rate being charged and the index base rate. The margins for HECMs are determined by law. HECMS usually are set at a 3.1 percent margin for annually adjustable loans and 1.5 percent for monthly adjustable reverse loans.

- Interest Rate Caps: This is the maximum margin that the lender can charge. This maximum may or may not be reached during the course of the loan. HECMs set the index rate cap for annually adjustable loans at 5 percent higher than the initial fully indexed rate, and set the cap for monthly adjustable loans at 10 percent higher than the initial fully indexed rate.

- Periodic Rate Adjustments: These are the changes made to the index base rate during the course of the loan. These adjustments are usually done annually, monthly, or bi-monthly. The maximum that can be applied to annually adjustable loans is 2 percent. The maximum for monthly adjustable loans is the current T-Bill rate plus margin (typically $1.5 \%$ ).

\section{Limitations}

The amount of equity a homeowner can access is determined by several factors.

- Age: Older homeowners can borrow more money, while younger borrowers are required to borrow less.

- Value: appraised value of the home and the amount of equity within the home.

- Interest rate: The higher the interest rate, the lower the available balance.
- Fees: Fees directly lower the amount you will be able to receive.

- Distribution type: In general, a line of credit gives you the highest loan amount, and lump sum gives you the lowest, with the other three falling somewhere in the middle. For more information on distributions, scan ahead to the next section.

The factors above, as well as others such as the lender and loan type, all come into play to determine the upper limit for your reverse mortgage amount. Keep in mind that the maximum loan amount for any reverse mortgage is $\$ 625,500$. To get a rough estimate of what you can expect from a reverse mortgage, check out AARP's calculator at: http://rmc.ibisreverse.com/default_aarp.aspx.

\section{Distribution Types}

You can be paid in one lump sum, on a regular monthly basis, as a line of credit, or at times and in amounts that you choose. These rates are determined by the amount of equity in your home and by the interest rate applied to the reverse mortgage. Your estate will pay the money back (plus interest) in the event you die, sell or move out of your home. The types of distributions are tenure, term, line of credit, modified tenure, and modified term. Tenure gives you equal monthly payments until the last living borrower dies or moves out of the house. Term pays out equal monthly payments for a specified number of months. Line of credit is paid in installments, at times and in amounts of your choosing until your credit limit is exhausted. Modified tenure is a combination of tenure and line of credit, and modified term is a combination of term and line of credit.

\section{Right of Rescission}

Under provisions of the Truth-in-Lending Act, borrowers have up to three business days following the signing of a reverse mortgage to cancel the transaction. This is called the "right of rescission." Business days include Saturday, but not Sunday or legal holidays. To cancel, you must do so in writing, using the proper form given by your lender. The letter must be delivered before midnight of the third business day. Notification of cancellation in person or 
over the phone will not work, only a written letter of cancellation will actually cancel the transaction.

\section{Beware of Unscrupulous Offers}

The Federal Deposit Insurance Corporation warns that some unscrupulous individuals or companies have promoted reverse mortgages that were not in the consumers' best interest or involved extra payments for unnecessary services. For example, there have been reports of companies attempting to sell questionable home repairs or investments in connection with a reverse mortgage.

One problem with using any loan product to fund an investment is that you could lose money on the investment and still owe on the loan.

Beware of firms that want to give you the name of a lender for a "small percentage" of a reverse mortgage loan. The U.S. Department of Housing and Urban Development (HUD) does NOT recommend using an estate planning service or any service that charges a fee just for referring a borrower to a lender-HUD provides this information without

cost. HUD-approved housing counseling agencies are available for free, or at minimal cost, to provide information, counseling, and free referral to a list of HUD-approved lenders.

Call 1-800-569-4287, toll-free, for the name and location of a HUD-approved housing counseling agency near you. You can always call your local Extension office for more information.

\section{References \& Resources}

AARP. (2003). Basic loan features. [Online]. Retrieved from http://www.aarp.org/money/personal/articles/ basicloanfeatures.html.

—. (2008). Reverse mortgage loans: Borrowing against your home. [Online] Retrieved from http://assets.aarp.org/www.aarp.org_/articles/money/ financial_pdfs/hmm_hires_nocrops.pdf and available at: Reverse Mortgages, Reverse Mortgage Education Program | AARP.org (n.d.). [Online]. http://www.aarp.org/money/revmort/.
Eldervantage, LLC and ReverseMortgagePage.com (2006). Reverse mortgage-What if one spouse is under 62? [Online]. Retrieved from http://www.reversemortgagepage.com/ topic.php?topID=22.

eXtension. (n.d.). What frauds do I need to be aware of with reverse mortgages? FAQ \#4854 | eXtension.org [Online]. Retrieved from http://www.extension.org/faq/4854.

FDIC. (Spring 2008). Money tips for all ages, after you retire: Managing your expenses on a fixed or reduced income. Consumer News - Special Edition. [Online]. Retrieved from http://www.fdic.gov/consumers/consumer/news/ cnspr08/expenses.html.

Federal Trade Commission. (April 2009). Reverse mortgages: Get the facts before cashing in on your home`s equity. [Online]. Retrieved from http://www.bbb.org. Available at http://www.ftc.gov/bcp/edu/pubs/consumer/homes/ rea13.shtm.

Kaplan, H. (2008). Reverse mortgages revisited. Partners in Community and Economic Development, 18 (3), 14-16. Atlanta, GA: Federal Reserve Bank of Atlanta-reprinted by permission, with updates, from the spring 2008 issue of Bridges, a Community Development newsletter published by the Federal Reserve Bank of St. Louis. [Online at FRBAtlanta.org]. Retrieved from http://www.frbatlanta.org/filelegacydocs/ Partnersv18n3.pdf.

Lafleur, D.P. (Winter 2008). Supervisory Insights, 5(2), 14-20. [Online]. Retrieved 1/08/09 from http://www.fdic.gov/regulations/examinations/ supervisory/insights/siwin08/si_win08.pdf.

Moore, C. (n.d.). Pros and cons of reverse mortgages | Bankrate.com. [Online]. Retrieved from http://www.bankrate.com/brm/news/mortgages/ 20070104_reverse_mortgage_a1.asp.

New Retirement, LLC. (n.d.). Comparing reverse mortgages: Reverse mortgage fees and rates | NewRetirement.com. [Online]. Retrieved from http://www.newretirement.com/Services/ Reverse_Mortgage_Fees.aspx. 
Porter, N. M., \& Schneider, M. R. (2007). Is a reverse mortgage right for you? FL 533. Clemson, SC: Clemson University Cooperative Extension Service. [Online]. Retrieved from http://www.clemson.edu/psapublishing/Pages/FYD/ FL533.pdf.

ReverseMortgage.net. (February 28, 2008). What is the difference between a mortgage and a reverse mortgage? [Online]. Retrieved from http://www.reversemortgage.net/mortgage-vs-reversemortgage/.

—. (April 17, 2008). What kinds of reverse mortgage plans are there? [Online]. Retrieved from http://www.reversemortgage.net/what-kinds-ofreverse-mortgage-plans-are-there/.

—. (April 26, 2008). Alternatives to obtaining a reverse mortgage. [Online]. Retrieved from http://www.reversemortgage.net/alternatives-reversemortgage/.

U.S. Department of Housing and Urban Development. (n.d.). About reverse mortgages for seniors (HECM) - HUD / FHA reverse mortgages (HECMs) for consumers | HUD.gov. [Online].

Retrieved from http://www.hud.gov/offices/hsg/sfh/hecm/ hecmabou.cfm. 